\title{
Colonial Structure, Chinese Minority and Racial Violence in Indonesia: A Social Reflection
}

\author{
Herdi Sahrasad \\ Senior Lecturer at University of Paramadina, Jakarta, Indonesia
}

\begin{abstract}
Under the Dutch colonial, the Dutch (white skin) become the political, economic and social elites in the colonial society, while middle class consisted of far east people (Chinese, Arab, India, etc), and bumiputera (indigenous Muslim) people laying in lower layer functioning producer of natural resources or traditional (feodal) elite. Dutch elites (top local officials, such as resident), Chinese elite (officer), and traditional elite (regents) are "Top Branch" of colonial society. The structure has been continuing in the era of Soekarno's Old Order and Soeharto's New Order. And under the New Order, the political practices of minority have serious social-political implications related to negative image that always inherent in Tionghoa (Chinese) people of Indonesia. The Indonesian Chinese (Tionghoa) often be assumed as source of various problems, simply could be 'scapegoat', if there are riots, economic crisis and racialism. Under the New Order, the Indonesian Chinese remain to treated as the others, the marginalized people.

In the post Soeharto's New Order 1998, however, the Chinese have been awakening gradually to join political parties and social organizations to take part in democratization and governance, even most of the Chinese conglomerates (taipan) has been the richest in Indonesia.
\end{abstract}

Keywords : Chinese; Tionghoa; racial; Dutch; colonial; Islam; Nurcholish Madjid; Indonesia; Muslim; reform; New Order; state.

\section{Introduction}

It has become truism to remark, tension between bumiputera (indigenous) Muslim and Tionghoa (Chinese) minority in different forms of anti-Chinese racial riots during the Soeharto's New Order regime (1966-1998) and transition era of BJ Habibie (1998-1999), actually connected with history of racial violence in colonial era and President Soekarno's Old Order era.

Regarding this complicated issue, Leo Suryadinata said that "In the eyes of most indigenous Indonesians, as long as the ethnic Chinese have not been completely absorbed into indigenous society, the 'Chinese problem' will remain." 1

In this connection, the late Prof Nurcholish Madjid, the guru bangsa (the teacher of the nation) and prominent Muslim scholar, admonish us in 1988 (about more than 20 years ago), that generally Indonesian people took exception to Chinese domination in economic sectors, and it is true that Tionghoa businessmen are primary force in the sector. According to Nurcholish Madjid, most of bumiputera (Indonesian indigenous) viewed that Tionghoa businessmen have questionable nationalism and patriotism. However, in other side, he said that people reluctant to discuss this issue as it be related to SARA (ethnic, religion, race, and group issues).

\footnotetext{
${ }^{1}$ Straits Times, 25 February 1998
} 
He then suggested that sooner or later the issue of Tionghoa economic domination could be solved properly, naturally and peacefully. ${ }^{2}$

What Nurcholish Madjid told about, is actually a "peak of ice mountain" of what sinologist, Wang Gungwu and Leo Suryadinata called it as the Chinese Problem in Indonesia, which it is impact and excess of continuous 'colonial structure', more lump up Soekarno's Old Order and Soeharto's New Order, until the fall of the New Order with massive social victims. $^{3}$

In this regard, continuity of colonial structure' in the context of Tionghoa and bumiputera (indigenous Muslim) relation in postcolonial Indonesia, characterized by continuous residue of prejudice, stigmatization, stereotype, social-economic segregation and ethnic polarization between Tionghoa minority and bumiputera (indigenous) majority, those are existing in the previous colonial era, but the problem remain unresolved essentially and properly by postcolonial regimes in Indonesia, both Old Order, and New Order, and current Reformation Order still making efforts to solve it.

Borrowing Furnival's perspective on plural society of Indonesian archipelago in colonial era, we saw that there are phenomena of formed plural society characterized by race and division of caste based on race. This is typical in west (Dutch) colonial society, in this term, Dutch Hindia. Raymond Kennedy and W.F. Wertheim have discussed how Dutch (white skin) become political, economic and social elites in the colonial society, while middle class consisted of far east people (Chinese, Arab, India, etc), and bumiputera (Muslim) people laying in lower layer functioning producer of natural resources or traditional (feodal) elite. Dutch elites (top local officials, such as resident), Chinese elite (officer), and traditional elite (regents) are "Top Branch" of colonial society. The structure has been continuing to Soekarno's Old Order and Soeharto's New Order ${ }^{4}$. Prof Daniel S Lev argued that the political practices of minority have serious social-political implications related to negative image that always inherent in

\footnotetext{
2 Nurcholish Madjid,' Indonesia Masa Mendatang, Ibarat Sosok Santri yang Canggih', Prisma, No. 5, 1988. In his different public lectures 1998-1999, Nurcholish Madjid (Cak Nur) frequently argued that New Order government made insincere policy to Tionghoa ethnic in which this minority group just brought into economic and trade direction, for interests of the governing regime. However, their political and cultural rights were under repression and prohibition of New Order, in consequence the Tionghoa ethnic become economic animals ignored other people, mainly pribumi Muslim who often be stubborn and conflict with them since colonial era to Old Order and New Order. See, Herdi Nurwanto (Herdi Sahrasad), 'Polarisasi social dan Kekerasan Politik: Studi tentang Kesenjangan antara Pribumi Muslim dan Etnis Tionghoa di Indonesia Era Orde Baru 19661998’, PhD dissertasion, unpublished, UIN Sunan Kalijaga, Yogyakarta, 2011.

${ }^{3}$ The author thanks to Prof Dr Leo Suryadinata (ISEAS \& National University of Singapore) and Prof Dr Hussein Mohammad (University of Malaya) for their inputs, comments, and suggestions for this paper during my independent research visiting the both universities 2005-2006.. See, Wang Gungwu dan Zheng Yongnian. China and the New International Order. London dan New York: Routledge,2007

4 JS Furnivall, 'Plural Societies"'. in: Evers, H.D. 'Sociology of Southeast Asia'. KL: Oxford Uni. Press, 1980: 86-96, Raymond Kennedy, "Southeast Asia and Indonesia", in R. Linton, (ed.), Most of the World Peoples of Africa, Latin America and the East, Columbia University Press, 1957 and W.F. Wertheim, Indonesian Society in Transition, The Hague, 1959. p.18-30
} 
Tionghoa people of Indonesia, mainly in Java. Tionghoa often be assumed as source of various problems alias simply could be 'scapegoat', if there are problems. ${ }^{5}$

As is commonly argued, indigenous Muslims tend to treat Indonesian citizen of Tionghoa as source of problems or scapegoat. This have evident not only dominant in New Order's regime era, but also since Dutch colonial era, mainly since minority politics gone into effect.

The political system admittedly designed to tackle and prevent forming of middle class that have possibility to be strong and can threat the colonial government, and intended to be used to establish secure and efficient social-economic structure.

Minority politics as had been practiced by the Dutch colonial government to Tionghoa citizen in Indonesia is similar to what had been practiced by British colonial government to India people in Myanmar, India and Tionghoa people in Malaysia, French government to Tionghoa people in Vietnam, etc ${ }^{6}$. The Dutch minority politics as practiced in Indonesia had been intensified through three ways. First, the colonial government intentionally isolated social intercourse of Tionghoa citizen and located them in certain settlement areas (pecinan). Second, created psychological mechanism in order that they always in fear and anxiety situations. Third, they had been forced to tie with a number of requirements and compensations with the colonial ruler.

It has long time that Tionghoa in Indonesia which apart from majority group and then stay in pecinan is permitted to earn their live freely in business sectors and even have possibility to be rich. Nevertheless, their live is still isolated from people majority and in consequence then they depend on power of the ruler in term of protection, and security. While their dependency is still kept with, still there are mechanisms of producing of fear and live in shadows of anxiety. There are common perceptions in majority (indigenous Muslim) about Tionghoa people, such as perceptions of the Tionghoa people since their born have talent of business, astute, tricky, and have no talent in other sectors, smart in get money, have no willingness to associate with other groups, etc. ${ }^{7}$ But actually there is the case in implicit contracts, in the past they had with colonial government always have a hidden requirement that more or less stated 'If there are something happens, who have to be blamed are minority groups'. These have happen in colonial region everywhere, still until New Order era. ${ }^{8}$

Residues of political influence of the minority, according to Dan Lev, is remained in modern Indonesian society in New Order era, that has been evident when majority people brutally treat the Tionghoa minority be blamed in months of May 1998 riots.

There are many people said that since their born, Indonesian citizens of Tionghoa clan have business talent and clear-headed in get money. Then, again and again, according to perceptions of the indigenous Muslim ${ }^{9}$, they are also frequently demonstrated have no big spirit to associate with other people outside of their group. On the contrary (in people

5 Daniel S Lev, Politik Minoritas, Minoritas dalam Politik,, seminar paper entitled ' Orang Indonesia- Tionghoa: Manusia dan Kebudayaannya', managed and organized by LIPI, Jakarta, 1/11/2002 p.1-12.. The late Lev is professor (Emeritus) of political science in the University of Washington, Seattle, USA.

\footnotetext{
${ }^{6}$ ibid

${ }^{7}$ Ibid

${ }^{8}$ Daniel Lev's conversation with journalists, Kompas, Thursday, 2 November 2000

${ }^{9}$ Interview with HMI and GPI activists, 14 November 2006 in Jakata.
} 
perceptions), they are tend to have exclusive behaviors; only want to associate intensely in their groups, such was the case.

Myths, prejudices and stigma about typical characters of the Tionghoa clan are still remained in Indonesian majority perceptions. Even, there is may be also similar case in perceptions of the Indonesian citizens of Tionghoa clan. Then, is there something wrong in historical journey of Indonesian nation, until the myths could extremely stay and live in Indonesian majority perceptions? To answer this question, Lev argued that it was Indonesian political system during New Order era that locating Indonesian citizens of Tionghoa clan as "minority citizens" around groups of Indonesian "people majority", which consisted of different ethnics and mainly dominated by Muslim (about 90 percents).

Since long time ago, far from the coming of VOC, Tionghoa people had individually come from China mainland in different waves to every outlying space of Indonesia regions. The coming of the "outlander and stranger" was never been assumed as strange, dangerous, or extraordinary, even for local people ${ }^{10}$

According to a sinologist and anthropologist, ${ }^{11}$ Prof Leonard Blusse, there are always processes of peaceful adaptation among outsiders of China mainland and local people. Even though, there have any conflicts among them as long as process of social adaptation, to borrow Dan Lev's perspective, that's common matter. Definitely, most of the coming of Tionghoa have not be refused and excommunicated by local people, or then be treated as scapegoat.

Pendulum of history indeed finally turned its direction. There is social and political dissociation of Tionghoa clan from local people. This has happened, mainly since Dutch colonial government was applying political system of minority, that actually similar to other Colonial systems in the world.

The minority politics had applied by Dutch colonial for specific reasons. Beside to create secure and efficient social-economic structure, it also intended for ward off opportunity to the forming of middle class among "indigenous Muslim". They are trader of indigenous Muslim, who potentially could threat the Dutch rule in Indonesia. For these purposes, local rulers, such as sultan or king in Java and outside Java- had be huddled up by Dutch colonial government through a political alliance.

At the same time, to fulfill vacuum of trader groups-middle class position that not interesting for Dutchmen, intentionally they have created (by excessive force exercised) a kind of agreement and contract with the minority group of Tionghoa. Since the time, political system of minority really has been applied for Indonesian citizens of Tionghoa clan, however, this not be applied for Indonesian citizens of Arab clan or other clans.

Currently, the minority political system has caused serious social-political implications in term of negative images on Tionghoa people in Indonesia, including pejorative comments in form of wrong myths about special characters of Tionghoa clan people.

Surely, the most tragic is tendency of Muslim people that easily stab downward the Tionghoa minority as cause and source of various problems. This happened as early as they

\footnotetext{
${ }^{10}$ ibid

${ }^{11}$ Prof Dr Leonard Blusse (Belanda) Proses Adaptasi Warga Keturunan Tionghoa dengan Warga Lokal, seminar paper with topic 'Orang Indonesia- Tionghoa: Manusia dan Kebudayaannya', conducted by LIPI, Jakarta, $1 / 11 / 2002$, p .2-10
} 
have been assumed as source of various problems that can be easily made as scapegoat if something wrong happened. ${ }^{12}$

The May 1998's riot, mainly in many places of Java, for many people, it has imparted strong impression about how the social incident seemingly intended to make Tionghoa people as its victims. The event, for Daniel Lev, is an obvious example about the growing of common people sentiment toward existence of the minority citizen. The event is not the first happened in Indonesia. In 1740, VOC even once mobilized Dutch and Javanese people to perform massacre to the minority group. In that event about 10.000 people were died. The action laden by burning of Tionghoa people's houses, massively from Jakarta to Semarang, thus it is logic to say that since long time ago, the minority group have excessively be marginalized, become scapegoat, and objects of people anger.

"Many Tionghoa people have died in the attacks, and highly possible that it caused by economic sentiment. Furthermore, the event has increasing a process of minority forming in the New Order era.

In fact, historical mistakes of the Dutch colonial government were continued in the New Order government. The worse, the New Order's political and social pressures to the minority groups had been intensified. Beside participation in political practice are be denied and even removed at all from the government bureaucracy, the minority group is also susceptible to get stigmatizing. The worst, they treated as source of various problems and scapegoat.

Meanwhile, their interdependence have been intensified in power circle-primarily related to issues of social security, protection, and economy-at the same time, they are continuously become economic "dairy cattle" for interests of the ruler and bureaucrats. It was not strange that in 1970s, emerging of the term of cukong, to call the rich people from Tionghoa clan, they are frequently act as "cashier" for interests of government apparatus and bureaucrats.

Therefore, it is not strange that in the further time-mainly as a consequence of protection and trade monopoly rights of the minority citizen, they become really skillful to manage trade business. This issue since long time ago has got "mandate" from Dutch colonial government; a policy that in fact, massively continued during the New Order government era. As they are dependent to the ruling power in term of security and protection of their business trade, thus the ruling power could be easily used for power interest, for instance, obligation of "fee". In the other word, the Tionghoa traders could be "used and pressed" continuously. These problems can be continued, only if the Tionghoa stay live in frame of social isolation and don't to be involved in political practices by become politician or legislature.

If finally corrupts cultures appear, playing money below table, collusion, and corruption, again and again the minority group who will be blamed by people. In indigenous Muslim perceptions, in fact they are have be accustomed with bribery, at least as stigma, which as if accusing the minority group as source of corruption cultures. It is seldom, for example, if we are honestly willing to say that in fact government apparatus and bureaucrats really tend to be evidently money mad, thus they willy nilly forced the minority group who have confined interests. Through that, misleading myths about the Tionghoa people become stronger. The bad stigmas more and more become in the New Order era. There were significant changes on what previously being called as Republik Rakyat Tionghoa/People Republic of Tionghoa (RRT) have to change to Republik Rakyat Cina/People Republic of China (RRC). That made serious consequence, as assimilation policy than obliged the naming

\footnotetext{
12 Daniel Lev ibid
} 
of "Tionghoa" has to change to "Cina/Chinese" as well, this undoubtedly has nuances of both degradation and abjection.

As the minority group become more be pressured and isolated, so the New Order regime easily could "revive" a number of previous requirements between the minority group and Dutch colonial government. From this situation then emerged the terminology of 'cukong" that has negative meaning, aggravated cynicism and anti-Tionghoa sentiment during the New Order era.

Therefore, sinologist, Charles Coppel ${ }^{13}$ noted, that there are Tionghoa ethnic's difficulties to be able to be received by Indonesian nationalists as a part of Indonesian nation. Coppel saw since colonial era until today, colonial society distinguished Indonesian people based on races/national ethnics, which influencing thought of Indonesian nationalists, consequently the Tionghoa clan be separated from Indonesian national movements. Besides, Tionghoa nationalism has coming early from Indonesian nationalism. The Tionghoa nationalism, including halfblooded, has growing separately from and intended by Indonesian government of 'the New Order regime' through assimilation policy. In one side, there are tendency to defend their ethnic identities in Tionghoa people. Even in other side, Hussein Muhammad (Professor of Sociology at University of Malaya), said they feel not yet become an integral part of Indonesian society.

Indonesian nationalism, according to Leo Suryadinata and Charles Coppel's perspective, has been constructed based on 'indigenism' concepts, and Tionghoa ethnic be categorized as Vreemde Oosterlingen, Foreign Oriental, who can be assumed as not a part of Indonesian nation. Indonetian nation be defined as 'property' of indigenous nation namely the Muslim majority, a group who possess their own land. Position of Tionghoa people in this situation, is clearly as 'stranger'. Above all, the concept of indigenous (Muslim) as host, has rooted from long time ago in the Indonesian archipelago. Tionghoa ethnic be assumed as nonindigenous and new comers who are unable to be received as Indonesian national ethnic prior to they are assimilating themselves. Moreover, the indigenous Muslim also has stereotypes on Tionghoa ethnic. They have perception that Tionghoa ethnic is an ethnic laying higher and separated economic level from indigenous Muslim (bumiputera). In consequence, concept of plural society with emphasizing at importance of ethnicity and nationality will always lay position of stranger, although they have status as Indonesian citizen.

\section{Misunderstanding and Misrepresentation}

In Indonesian nation, including, the late Nurcholish Madjid, I think actually there are not many people understand that majority of Tionghoa people in Indonesia, they still feel themselves as marginalized and alienated group from bumiputera (indigenous) in their neighborhood. Tionghoa people only consisted about 2-3\% of Indonesian population.

${ }^{13}$ Charles Choppel is emeritus professor at Melbourne University, Australia and wrote dissertation on Tionghoa ethnic 1966 crisis and racial violent to Tionghoa ethnic in 1970s. See Charles Choppel, Indonesian Chinese in Crisis, Kuala Lumpur: Oxford University Press 1983. See also, Charles Choppel , 'Researching the Margins, in Tim Lindsey,Helen Pausacker, Editors, Chinese Indonesians: Remembering, Distorting, Forgetting, Singapore: Institute of Southeast asian Studies, 2005 
Although for centuries lived in Indonesia, they still feel unrepresented and become the other or the alien among the plural nation of Indonesia. Charles A. Coppel, Indonesianist and Australian sinologist who spent a half of his life for study on Tionghoa ethnic in Indonesia, saw there are alienation and marginalization feelings that go on since colonial era, hundreds years ago until present time.

In consequence, if we discuss about relation between indigenous Muslim (bumiputera) and Tionghoa ethnic, there will arise shadow of poignancy, tension, and hidden crisis. Relationship between indigenous and Tionghoa never get out of distrust and disharmony circles. Once in a while, it characterized by dichotomy and antagonistic tension. AntiTionghoa sentiment in the indigenous (bumiputera), in fact, not totally disappeared in current multidimensional crisis. ${ }^{14}$ Memory about the May, 1998 riot, for example, is extremely heartbreaking, absurd and painful. Tionghoa ethnic in the May 1998 tragedy, likely had been forced, oppressed, victimized, and marginalized. Whereas many of them are ordinary people as other Indonesian people. The New Order regime has clearly mistake, however, can that not be repeated by the next regime? It is a question that always waiting for answer and uncertainty.

The May 1998 riot has appaled the world and caused formidable suffering to not only Tionghoa in Indonesia, but also the indigenous (bumiputera). The tragedy has indirectly leads the Tionghoa to inferior position and become object. After the tragedy, it is without deceit that there were emerged questions from Arief Budiman, Ariel Heryanto, Mochtar Riadi, Ciputra, Lin Che Wei and Kwik Kian Gie, is that the Tionghoa ethnic a part of Indonesian nation or they are foreigner, the other or outsider who are not part of Indonesian nation?

The question, indirectly reflecting that, in fact during the time, Tionghoa, is an ethnic of Indonesian nation that continuously become object - or at least lead to be object - in several bad cases, mainly in term of SARA related (ethnic, religion, race, and intergroup).

In broader context, anti-Tionghoa riots in the New Order era more or less produced by role of the New Order Regime, which during they in power, was implemented injustice, unequal, undemocratic and weak economic and political system, caused difficulties for Tionghoa to integrate to Indonesian nation. ${ }^{15}$

Since May 1998 tragedy and the fall of the Soeharto's New Order regime and beginning of the Reformation era, there are many changes in social-political life of Tionghoa people in Indonesia. The different cases raised awareness in Tionghoa about is there something wrong in their life?

The Tionghoa then aware that the May 1998 tragedy actually is "repetition" of similar tragedies happened in the period of G30S and PKI extermination (1965-1969), where thousands of Tionghoa people throughout Indonesia be alleged those have involved in PKI, being hunted and caught to be treated as objects of extortion. They have remarkable and prolonged trauma. Therefore, the Tionghoa in the New Order era keep away from political field. They are not forget that there were thousands of school and some universities both established by Baperki or Tionghoa's foundations being closed and their buildings used as army barracks/student action movement secretariats, which then turned into public school, shops and offices.

14 Tim Lindsey \& Helen Pausacker,editors, Chinese Indonesian, Remembering, Distorting, Forgetting, Singapore: Institute of Southeast asian Studies, 2005

${ }^{15}$ Leo Suryadinata, Negara dan Etnis Tionghoa, Jakarta: LP3ES, 2002 
Actions of the New Order regime in 1966-1968 that prohibited the using of Tionghoa language, alphabet letter, and religious, cultural, and traditional ceremonies, as well as replacement of the terminology of Tionghoa by the pejorative terminology, Cina (Chinese), and also the establishing of Coordination Body of China Matters (Badan Koordinasi Masalah Cina) (BKMC) have caused fear and reluctant in majority of Tionghoa to involve in political fields. They gradually had been brought by the regime to only involve in business fields and be confined in there about 32 years until the fall of the New Order regime. The sadden thing, borrowed what Kwik Kian Gie and Benny G Setiono said-, the New Order efforts to keep a few of Tionghoa entrepreneurs to be their cronies in wealth accumulation, through developing the system of percukongan (matters regarding big financiers), which provide certain facilities produced black conglomerates and caused bad image in people perception. This is extremely adverse all Tionghoa.

The 13-15 May 1998 tragedy also demonstrated that without political supports, position of the Tionghoa people in Indonesia, according to public, it is myth that they are likely "very strong" in economic field, actually they are extremely vulnerable and can be over a barrel by riots. This also proven it is wrong conviction of some Tionghoa people that most secure protection is by stick themselves to the ruling elites.

During the happening of May riot, through mass media, people in the world clearly saw there were "the letting of" by security officials with the result that the anarchical actions could be happen freely without any efforts to hinder them. It was no long time after the fall of the New Order regime, appeared a number of NGO, mass organization, and political parties, established by Tionghoa with each own vision and mission. Especially after the President, Abdurrahman Wahid (1999-2001) issued Presidential Decision (Keppres) gave freedom for the Tionghoa in perpetrating of religious, cultural, and traditional rituals, and also Presidential Decision (Keppres) of the President, Megawati (2002-2004) made Imlek become national holiday. Administration in the era of the President, Susilo Bambang Yudhoyono-Vice President, M Jusuf Kalla (SBY-Kalla) even issued Citizenship Law No.12/2006 eliminated discrimination to the Tionghoa ethnic. In consequence, there is enormous euphoria in the Tionghoa people, so that they are occasionally broke the rules. Thus, sociologist Arief Budiman, patiently warned the Tionghoa people to refrain themselves since he afraid they will continuously break the rules and caused anger of indigenous (bumiputra) people.

\section{The New Order, Muslim and Tionghoa Ethnic}

Arief Budiman in his writing ${ }^{16}$, described the New Order elites have generally be aware of the increasing of strong indigenous middle class will threat their existence. The elites afraid of indigenous (indigenous Muslim) entrepreneurs will oppose them if they have significant amount of capital. Meanwhile, in other side, there are Tionghoa group who economically well enough, but have no political power. So they have been "huddled up" by the elites and got special treatment in business sectors, in return they help the ruling regime (plus their followers) by their fund. There are significant amount of cooperation and corruption, and the "unequal and abnormal" social economic movements are not secure the Tionghoa position, even extremely increased aversion of indigenous mass (Muslim) to the Tionghoa ethnic.

\footnotetext{
${ }^{16}$ Arief Budiman, "The Emegence of the Bureaucratic Capitalist State in Indonesia" in Lim Teck Ghee (editor), Reflections on Development in Southeast Asia, Singapore: ISEAS, 1988
} 
In this context, Jemma Purdey's perspective, an Indonesianist from Australia, ${ }^{17}$ affirmed the Arief Budiman's perspective. Even in his book, from his $\mathrm{PhD}$ dissertation in Melbourne University, he explained deeply how patterns of anti-Tionghoa racial riots periodically have done by actors of the New Order regime, criminals, military agents and loyalists of the regime, who are tremendously urged mass to make the anti-Tionghoa violent and anarchical actions. In consequence, during the New Order era, the issue of majority-minority relations, especially in racial riots involved Indonesian citizens from Tionghoa clan, almost never be stopped and unresolved. It is easy to assume that, there were more Tionghoa people than other groups, minority or majority, who become victims of plundering, incendiary, killing, maltreating, and raping. Certainly, these caused long-lasting suffering and trauma.

Of course, minority groups in Indonesia are not only the people of Tionghoa clan. There are also minority groups based on religion, ethnicity, culture, or language. They are Budhist, Hindus, Christian-Catholic, or Batak, Toraja, Acehnese, etc. However, surprisingly may be cause of historical and other factors, the Tionghoa is in fact always be a race group, who in the era become and becoming the most protruding minority problem, though there are other racial groups, for instance Arab group. Therefore, it is highly argued that the problem is not only a minority problem, and not only about citizen from Tionghoa clan. However, the core fundamental problem is that the government, especially security officials, has failed to protect their citizens, regardless their backgrounds.

People of Tionghoa clan likely are intentionally made as main object of rioters in the New Order era, who are provoked a mass fury. The provocation has been aimed to disgrace and discredit student reformation movements. In this context, Tionghoa clan factors have easily used as a toll for the objective. Firstly, because there is formed perception and image in indigenous (bumiputera), though may be never proved factually, that as if Indonesian wealth in the hands of Tionghoa, this caused broader social-economic disparity. The perception and image frequently have been developed by political elites, intentionally or unintentionally, caused anti-Tionghoa sentiment (Sudjati Djiwandono, 1998). Secondly, the perception and image also be fertilized by certain elites of Tionghoa themselves in business sectors, plotted with the government, over lived high and frankly exhibited it. This caused envy, even may be aversion, to them and the government, including in Tionghoa itself. No long time after the fall of the New Order regime, there are arising of differen NGOs, mass organizations, and political parties, which be established by various circles of Tionghoa with their own vision and mission. Especially after the President, Abdurrahman Wahid (1999-2000) issued Presidential Decision (Keppres) that gave freedom for Tionghoa to perpetrate religious, tradition, and cultural rituals, and also Presidential Decision (Keppres) of the President, Megawati, who made Imlek as national holiday, there is formidable euphoria in Tionghoa, with the result that sometime they broke the rules. Arief Budiman wrote, the Tionghoa then refrain themselves to prevent them to unintentionally break the rules, and cause aversion of indigenous (bumiputra) people.

It is highly argued that, under the New Order regime era, Tionghoa people only concentrated in business/economic sectors. And, according to Leo Suryadinata, for most of indigenous (bumiputera/muslim majority), there is still strong perception that as long as Tionghoa ethnic not be integrated to indigenous (bumiputera) people, so the Tionghoa issue would be unresolved. So, it is unsurprised that, immediately when the reformation era was

${ }^{17}$ Jemma Purdey PhD, Anti-Chinese Violence in Indonesia 1996-1999, Singapore: National University of Singapore Press, 2006 
begun, the Tionghoa tried to disclose reality behind myths that created social base for emergence of racism and xenophobia to Tionghoa in Indonesia. Even, by learn from its history, there are changing perception, attitude, and action in the Tionghoa to seek and enter the democratized social, political, and cultural sphere. The Tionghoa people in the reformation era entered other sectors, which for 32 years was closed for them. The Tionghoa, now have bravely go forward to struggle for their rights as citizens, they strive for cancellation of all discriminative laws, for example, the actual issue of Proof Document of Republic of Indonesia Citizen (SBKRI).

So far, according to a number of researchers, NGO activists, and experts, 'a slight of hopes" arose from participation, emancipation, and involvement of Tionghoa people in different non-business sectors. Tionghoa activities as "civil society' in reformation era, or the post Soeharto's New Order 1998, as follows:

First, Group with a notion that Tionghoa ethnic have to establish their own political parties to be able to struggle for their interests and rights directly in Parliament (PARTI headed by Lieus Sungkharisma and PBI headed by Nurdin Purnomo, which then be split by establishing of PPBI headed by Dr.Frans Tsai).

Second, Group that directly integrated in Indonesian people through establishing of NGOs, which opposed discriminative laws and actions, for instance Solidaritas Nusa Bangsa (National Solidarity) headed by Ester Indahyani Jusuf SH. and GANDI.

Third, Tionghoa people who contend that they have no problem with their Tionghoa identity feel that they have fully become part of Indonesian. They are directly involved in political parties and successfully become legislatures and even ministers (Kwik Kian Gie PDIP, Tjiandra Wijaya Wong-PDIP, Alvin Lie-PAN, Enggartiasto Lukita - Golkar for DPR and also for MPR Daniel Budi Setiawan -PDIP and Siti Hartarti Murdaya - group representatives during BJ Habibie era (1998-1999).

Fourth, group that only wanted to struggle for rights of Tionghoa ethnic, mainly in defence of their social, cultural and ethnic identity. They avoid political arena (PSMTI headed by Brigjen Purn. Tedy Jusuf).

Fifth, Group that wanted to solve Tionghoa issues holistically through as many as possible assembling Tionghoa people in an organization to be together with other national components to solve Indonesian actual issues, toward the new justice, welfare, and highly civilized Indonesia, so that it be competitive in the context of globalized world (INTI Union headed by Eddie Lembong).

Sixth, Businessmen who during the time realize that their aspirations are unreprented by KADIN, they established Indonesian Tionghoa Bussinessmen Association headed by Sofyan Wanandi and Sukanta Tanuwijaya (P.T.Great River Indonesia).

Seventh, The rests, hundreds of organization entire regions of Indonesia established by "totok" Tionghoa, in form of foundation, club or union, which generally based on or village in China mainland (Hokkian, Hakka, Kongfu, etc) and based on clan (Liem, Wong, etc). Also many of them including death union, association, alumni of Tionghoa schools and foundations of education, health, arts, and culture, which established only based on family union and wistfulness, and also highly avoid political arena. Art and cultural union of barongsay and liong, generally based on Chinese temples (kelenteng) in entire cities of Indonesia.

In the era of Susilo Bambang Yudhoyono-Jusuf Kalla (SBY-Kalla), an economist, Djisman Simanjuntak, said that in Indonesia, indigenous people (kaum bumiputera) are the holders of political power, while Tionghoa are the holders of economic sectors. In social 
reality, dichotomy between indigenous (bumiputera) and Tionghoa still existed in terms of pribumi (indigenous) and nonpribumi (non-indigenous), although Citizenship Law presently has eliminated the dichotomy. According to Djisman, economic nationalism in Indonesia is remaining strong as "driving force" for national economy, which in certain levels affecting economic and business policy in Jakarta ${ }^{18}$.

Djisman, a CSIS's economist, argued that the President, Susilo Bambang Yudhoyono (SBY), more interested to pragmatic economic policies as Indonesia in fact highly requires foreign investment for economic recovery. While, the former vice-president, Jusuf Kalla (JK) still wanted affirmative policy for indigenous (bumiputera) with consideration of social justice and economic distribution aspects, which those are sensitive and complicated issues in Indonesia. The contradicting perception between SBY and JK affected the government economic policies on the Tionghoa minority. However, it has not caused anti-China sentiment. Meanwhile during the time, Tionghoa people still split up between totok and qiaosheng Tionghoa.

Djisman recognized that there is impact of the rising of China economy to Tionghoa businessmen. However, is it unclear that the impact is either negative or positive them, or the impact is not significant. Djisman stated that the Vice-President, Jusuf Kala still believed that policies of indigenous empowerment are extremely vital, and Kalla argued that affirmative policy for indigenous (bumiputera) required to supports their growth, without discriminating of the Tionghoa. Meanwhile, the President, SBY showed his non-racial attitudes, but even supporting cooperation between the indigenous and the Tionghoa. ${ }^{19}$

(Chinese traders and conglomerates) in building the state and society post Soeharto's New Order.

In my interview with many Chinese traders and intellectuals in Jakarta recently, most of the Tionghoa people are very worry with the Jakarta Governor Ahok (Basuki Tjahaya Purnama) style and character, especially the Indonesian Chinese middle class. Why? Because the sentiment of anti-Chinese could rekindled among the bumiputera (indigenous) communities following Ahok policy to displacing the poor in various places in Jakarta.

The Taipan Chinese should also be aware that although the New Order era of economic growth and reforms have increased the number of Muslim middle class, a large proportion of the majority of Muslim community is still poor. Also, economic disparity and imbalances between Muslims and the Chinese people more broadly and deeply.

In fact, according to Robert Hefner, Muslims account for almost 88 percent of the Indonesian population, and in the days before colonization, they are carriers of one of the mercantilist tradition that boasts the world's largest. Muslim traders and businessmen have strong position and role in strengthening the santeri middle class to promote democracy and freedom.

But the Muslim middle class is very little compared to Chinese conglomerates who dominated the Indonesian economy.

\footnotetext{
${ }^{18}$ Leo Suryadinata, Editor, Southeast Asia's Chinese Businesses in An Era of Globalization, Coping with the Rise of China, Singapore: Institute of Southeast Asian Studies (ISEAS), Singapura, 2006, p. 49-75
}

${ }^{19}$ Ibid, p. $97-98$ 
Most of today's conglomerate owned and run by Chinese businessmen who have close ties with the Indonesian political elite (Booth, 1992). ${ }^{20}$ Statistical data on the ethnic share in the business of Indonesia have confirmed the widening gap between Muslims and the Chinese people have. In the mid-1980s -1990an, it is about 70-75 percent of domestic private capital is owned by the Chinese (Robison, 1986). ${ }^{21}$

This ethnic concentration more intense given the fact that as a group, the Chinese people only 2-3 percent of the total population of bumiputera. Gordon Redding and Onghokham noted that about 70 percent of the assets of the national economy remained amid the ethnic Chinese. Again, dedication and greatness of soul of the Taipan Chinese to " share solidarity and commitment " to invest in Indonesia, is a rational and objective solutions to overcome tensions and the gap between the Muslim Bumiputera (indigenous Muslims) and the Chinese.

If each has empathy, tolerance and equal civility, it is no longer need to occur racial riot in Indonesia, as it did in the May 1998 riots and various racial riots that continued in 1999. Under reform era, the citizenship law has been implemented by President Abdurrahman Wahid in 2001 and this new law was welcomed by the Chinese citizens. By way of that, then the Chinese citizens has become an integral part of our nationwith their political, social and cultural rights.

In this context, however, I would like to reaffirm the view of Robert Hefner that although attitudes of the Muslims toward the market and capitalism has greatly changed, there is still a difficult problem in the public perception of the new capitalism in Indonesia in connection with the economic domination by the Chinese tycoons. So that, if we compare it with the citizens of Indonesian Chinese, there is a strong belief that Muslims do not enjoy the sharing of the fair economic pie. Due to economic domination by Chinese tycoons, sense of injustice and resentment was deepened and hardened among the Muslims during the New Order era, even reform era to the present day. Most of the Muslims are demanding economic democracy, social justice and equality. They are desperated with Chinese conglomerates who dominated Indonesian economy because it is contrary and against the Indonesian constitution and Pancasila ideology (state ideology).

\section{Conclusion}

In this regard, the Muslims appreciate vigorously if many Indonesian Chinese want to live together inclusively with indigenous Muslim (Muslim bumiputera). Inclusiveness of the Chinese minority towards the indigenous people and vice versa, is very good for the natural integration of both parties. In this way, prejudice and suspicion between the Chinese and indigenous minorities can be eroded in real terms.

The Chinese and the indigenous people can cooperate and work hard together to eliminate inheritances of dibbling colonial system, so that what the so-called the anti-Chinese tensions between the Chinese and indigenous (bumiputera) in the past, could be decreased and unrepeated in the future. Thereby, state and nation building in Indonesia could be implemented significantly and simultaneously in the long time.

\footnotetext{
${ }^{20}$ Anne Booth, Editor, Indonesian Economy During the Socharto Era, Oxford University Press, April 1982

${ }^{21}$ Richard Robison, Indonesia: The Rise pf Capital, Sydney: Allen and Unwin, 1986
} 


\section{References}

Arief Budiman, "The Emegence of the Bureaucratic Capitalist State in Indonesia" in Lim Teck Ghee (editor), Reflections on Development in Southeast Asia, Singapore: ISEAS, 1988

Anne Booth, Editor, Indonesian Economy During the Socharto Era, Oxford University Press, April 1982

Daniel S Lev, Politik Minoritas, Minoritas dalam Politik, seminar paper entitled 'Orang Indonesia- Tionghoa: Manusia dan Kebudayaannya', managed and organized by LIPI, Jakarta, 1/11/2002 .

Jemma Purdey PhD, Anti-Chinese Violence in Indonesia 1996-1999 , Singapore: National University of Singapore Press, 2006

JS Furnivall, 'Plural Societies', in: Evers, H.D. 'Sociology of Southeast Asia'. KL: Oxford Uni. Press, 1980: 86-96,

.Herdi Sahrasad (Herdi Nurwanto), 'Polarisasi social dan Kekerasan Politik: Studi tentang Kesenjangan antara Pribumi Muslim dan Etnis Tionghoa di Indonesia Era Orde Baru 1966-1998', PhD dissertasion, unpublished, UIN Sunan Kalijaga, Yogyakarta, 2011.

Herdi Sahrasad, "Struktur Kolonial, Etnis Tionghoa dan Kerusuhan Rasial', Jurnal Paramadina, No.5 Juli 2007.

Leonard Blusse (Belanda) Proses Adaptasi Warga Keturunan Tionghoa dengan Warga Lokal, seminar paper with topic 'Orang Indonesia- Tionghoa: Manusia dan Kebudayaannya', conducted by LIPI, Jakarta, 1/11/2002,

.Leo Suryadinata, Editor, Southeast Asia's Chinese Businesses in An Era of Globalization, Coping with the Rise of China, Singapore: Institute of Southeast Asian Studies (ISEAS), Singapura, 2006.'

Leo Suryadinata, Negara dan Etnis Tionghoa, Jakarta: LP3ES, 2002

Raymond Kennedy, "Southeast Asia and Indonesia", in R. Linton, (ed.), Most of the World Peoples of Africa, Latin America and the East, Columbia University Press, 1957

Richard Robison, Indonesia: The Rise pf Capital, Sydney: Allen and Unwin, 1986

Tim Lindsey \& Helen Pausacker,editors, Chinese Indonesian, Remembering, Distorting, Forgetting, Singapore: Institute of Southeast asian Studies, 2005

W.F. Wertheim, Indonesian Society in Transition, The Hague, 1959

\section{Journal:}

Prisma, Nurcholish Madjid," Indonesia Masa Mendatang, Ibarat Sosok Santri yang Canggih', Prisma, No. 5, 1988.

\section{Newspapers:}

Straits Times, 25 February 1998

Kompas, Daniel Lev's conversation with journalists, Kompas, 2 November 2000

\section{Acknowledgements:}

The writer would like to thank Prof Laurie Sears (University of Washington,Seattle) and Prof M Steven Fish (University of California Berkeley) for their kindness during my research days to finish this paper in February-April 2012 in UW Seattle and UC Berkeley, but the responsibility of the paper is the writer alone. 